\title{
Association of marine Collagen/Biosilicate composites and photobiomodulation in the process of bone healing using an experimental model of calvarial defect
}

\author{
Associação de compósitos de colágeno marinho/biosilicato e fotobiomodullação no processo de \\ consolidação óssea usando um modelo experimental de defeito na calvária \\ Asociación de compuestos de colágeno marino/biosilicato y fotobiomodulación en el proceso de \\ cicatrización ósea utilizando un modelo experimental de defecto de calvaria
}

Received: 05/25/2021 | Reviewed: 05/31/2021 | Accept: 06/23/2021 | Published: 07/05/2021

Giovanna Caroline Aparecida do Vale ORCID: https://orcid.org/0000-0002-5375-1241 Federal University of São Paulo, Brazil E-mail: gica.vale@ hotmail.com.br

Kelly Rossetti Fernandes

ORCID: https://orcid.org/0000-0003-2851-6896 Federal University of São Paulo, Brazil E-mail: kelly.fernandes@unifesp.br

Julia Risso Parisi

ORCID: https://orcid.org/0000-0002-4325-0638

Metropolitan University of Santos, Brazil E-mail: juliaparisi@outlook.com

Alan de França Santana

ORCID: https://orcid.org/0000-0001-8213-8262 Federal University of São Paulo, Brazil E-mail: alandefranca@hotmail.com

Matheus de Almeida Cruz

ORCID: https://orcid.org/0000-0002-9032-9111 Federal University of São Paulo, Brazil E-mail:allmayda07@gmail.com

Carlos Alberto Fortulan ORCID: https://orcid.org/0000-0002-2259-9910 University of São Paulo, Brazil E-mail:fortulan@usp.br

Edgar Dutra Zanotto

ORCID: https://orcid.org/0000-0003-4931-4505 Federal University of São Carlos, Brazil E-mail: dedz@ufscar.br

Oscar Peitl

ORCID: https://orcid.org/0000-0002-9852-662X Federal University of São Carlos, Brazil E-mail: opeitl@ufscar.br

Renata Neves Granito

ORCID: https://orcid.org/0000-0002-2094-3845 Federal University of São Paulo, Brazil E-mail: re_neves@yahoo.com.br

Ana Claudia Muniz Rennó

ORCID: https://orcid.org/0000-0003-2358-0514 Federal University of São Paulo, Brazil E-mail: acmr_ft@yahoo.com.br

\begin{abstract}
The study comparing the bone regenerative capacity in an experimental model of cranial bone defects in rats, into 3 groups: G1: bone defects irradiated with photobiomodulation; G2: Biosilicate + photobiomodulation and G3: Biosilicate and Spongin + photobiomodulation. Histocompatibility and bone responses were performed after 15 and 45 days of implantation. Histological analysis demonstrated that photobiomodulation irradiated animals presented an increased amount of newly formed over time. Histomorphometry showed higher values for bone volume for G3 and G1, higher values for osteoid volume and number of osteoblasts observed for G3 compared to G2. TGF- $\beta$ immunolabelling was higher for G2. The values found for VEGF were higher for biosilicate (with or without spongin) 15 days of implantation with an increased difference being observed for G1, 45 days after surgery. In conclusion, the stimulus provided by photobiomodulation associated to the biomimetic composite increased bone formation in the cranial bone defect in rats.
\end{abstract}


Consequently, these data highlight the potential of the introduction of spongin into biosilicate and irradiated with photobiomodulation to improve the biological performance for bone regeneration applications.

Keywords: Photobiomodulation; Biomaterials; Tissue engineering.

\section{Resumo}

O estudo comparou a capacidade regenerativa óssea em modelo experimental de defeitos ósseos cranianos em ratos, em 3 grupos: G1: defeitos ósseos irradiados com fotobiomodulação; G2: Biosilicato + fotobiomodulação e G3: Biosilicato e esponja marinha + fotobiomodulação. A histocompatibilidade e as respostas ósseas foram realizadas após 15 e 45 dias de implantação. A análise histológica demonstrou que os animais irradiados com fotobiomodulação apresentaram um aumento da quantidade de neoformados ao longo do tempo. A histomorfometria mostrou maiores valores de volume ósseo para G3 e G1, maiores valores de volume de osteóide e número de osteoblastos observados para G3 em relação ao G2. A imunomarcação de TGF- $\beta$ foi maior para G2. Os valores encontrados para VEGF foram maiores para o biosilicato (com ou sem esponja marinha) 15 dias após o implante, com diferença aumentada sendo observada para o G1, 45 dias após a cirurgia. Em conclusão, o estímulo fornecido pela fotobiomodulação associada ao compósito biomimético aumentou a formação óssea no defeito ósseo craniano em ratos. Consequentemente, esses dados destacam o potencial da introdução da esponja marinha no biosilicato e irradiada com fotobiomodulação para melhorar o desempenho biológico para aplicações de regeneração óssea.

Palavras-chave: Fotobiomodulação; Biomateriais; Engenharia tecidual.

\section{Resumen}

El estudio comparó la capacidad de regeneración ósea en un modelo experimental de defectos óseos craneales en ratas, en 3 grupos: G1: defectos óseos irradiados con fotobiomodulación; G2: Biosilicato + fotobiomodulación y G3: Biosilicato y Spongin + fotobiomodulación. La histocompatibilidad y las respuestas óseas se realizaron a los 15 y 45 días de la implantación. El análisis histológico demostró que los animales irradiados con fotobiomodulación presentaron una mayor cantidad de recién formados con el tiempo. La histomorfometría mostró valores más altos para el volumen óseo para G3 y G1, valores más altos para el volumen osteoide y el número de osteoblastos observados para G3 en comparación con G2. El inmunomarcaje de TGF- $\beta$ fue mayor para G2. Los valores encontrados para VEGF fueron mayores para el biosilicato (con o sin esponja) a los 15 días de la implantación, observándose una mayor diferencia para G1, 45 días después de la cirugía. En conclusión, el estímulo proporcionado por la fotobiomodulación asociada al compuesto biomimético aumentó la formación de hueso en el defecto óseo craneal en ratas. En consecuencia, estos datos destacan el potencial de la introducción de espongina en biosilicato e irradiado con fotobiomodulación para mejorar el rendimiento biológico para aplicaciones de regeneración ósea.

Palabras clave: Fotobiomodulación; Biomateriales; Ingeniería de tejidos.

\section{Introduction}

Bone fractures are one of the most important health problem in orthopedic clinics, affecting more than 9 million people every year (Pisani et al., 2016). Bone tissue has the ability of healing by itself in most of the situations but, in some specific occasions such as a fracture with large dimensions or associated diseases (such as osteoporosis), the process of consolidation can be impaired, being necessary the use of therapeutical interventions (Einhorn \& Gerstenfeld, 2015).

In this context, the stimulating effects of photobiomodulation (PBM) on the process of bone healing have been demonstrated by many authors (Hamblin 2017; Farivar et al., 2014; de Freitas \& Hamblin, 2016). PBM, an electromagnetic energy, is able of increasing mitochondrial activity and cellular metabolism, culminating in an upregulation of the synthesis of proteins and enzymes, increasing of cell proliferation and improvement of tissue oxygenation (Farivar et al., 2014; de Freitas \& Hamblin, 2016; Karu, 2008; Bossini et al., 2012). Due to all these modifications, PBM has positive effects on neoangiogenesis, on the modulation of the inflammatory process and on the acceleration of tissue repair, including bone (Farivar et al., 2014; Fernandes et al., 2013; Tim et al., 2015; Magri et al., 2015). PBM applied to the site of the fractures or bone defects up-regulates the synthesis of genes and proteins related to osteoblast cell proliferation and differentiation and increases newly formed bone deposition (Fernandes et al., 2013; Tim et al., 2015).

Another very promising treatment for accelerating the process of bone consolidation is the employment of active biomaterials, which bond and integrate with living bone (Fernandes et al., 2017b). In this context, it is possible to highlight the osteoinductive effects of Biosilicate (BS) (a crystallized bioactive glass-ceramic with the composition of $\mathrm{P} 2 \mathrm{O} 5-\mathrm{Na} 2 \mathrm{O}-\mathrm{CaO}-$ 
$\mathrm{SiO} 2$ ). The rapid reactions of BS with bone and its dissolution, releasing ions such as silicon, calcium, phosphorus and sodium ions stimulates the proliferation, attachment and activity of bone-forming cells, promoting tissue ingrowth and accelerating the process of bone healing (Oliveira et al., 2009; Moura et al., 2007; Granito et al., 2009; Fangel et al., 2011; Granito et al., 2011; Matsumoto et al., 2012; Kido et al., 2013; Pinto et al., 2013; Kido et al. 2017; Fernandes et al. 2017a). The inclusion of collagen (Col) on BS, in order to constitute a bone biomimetic graft (a mineral part and an organic part) has been used by some authors as well (Gabbai-armelin et al., 2015; Gabbai-armelin et al., 2017; Ueno et al., 2016). It is well known from the literature that Col, the most common protein of vertebrates, is also an efficient bone substitute able of stimulating healing (Silva et al., 2014; Lin et al., 2011).

Although, the most frequent sources of $\mathrm{Col}$ is the bovine and porcine tissues, recently marine $\mathrm{Col}$ has been emerging as an alternative, especially the ones from marine sponges (Gabbai-armelin et al., 2017; Silva et al., 2014; Lin et al., 2011). Marine sponge Col or spongin (SPG), is a very innovative Col, being analogous to type XIII human Col (Gabbai-armelin et al., 2017; Silva et al., 2014; Lin et al., 2011; Green et al., 2003). SPG is secreted by cells known as spongocytes and it is (Green et al., 2003) and has been demonstrated by many authors to be a suitable framework for attachment, migration and proliferation of osteoblasts (Green et al., 2003; Exposito et al., 2002; Iwatsubo et al., 2015). Additionally, some authors have also demonstrated the stimulating results of BS/SPG composites on the healing of bone injuries, showing very positive results (Pisani et al., 2016).

As described above, there are many scientific evidences showing the positive outcomes of PBM and BS (isolated or in association with SPG) on the process of bone healing (Fangel et al., 2014; Pinto et al., 2013; Bossini et al., 2011). However, no previous study has investigated the effects of PBM on bone defects treated with BS/SPG composites. The association of an extraoperative technology (PBM) with a biomimetic bone graft may constitute an optimized treatment for improving bone regeneration, especially in the cases of non-union fractures or pseudoarthrosis. In this context, this study was the aim to investigate the effect of SPG associated to PBM and BS on the process of bone regeneration in an animal model. In vivo studies were conducted, comparing the bone regenerative capacity in an experimental model of cranial bone defects in rats. Histocompatibility and bone responses, trough histology, histomorphometry and immunohistochemical analysis, were performed after fifteen and forty-five days after the surgery process.

\section{Methodology}

\subsection{Biomaterials}

Biosilicate: BS was provided by the Vitreous Materials Engineering Laboratory, Federal University of São Carlos, (São Carlos, SP, Brazil). The material particle size used in the present work ranged from 250 to $1000 \mu \mathrm{m}$.

Spongin: The SPG was extracted from Aplysina fulva marine sponge, collected in Praia Grande (São Sebastião, Brazil). The process of SPG extraction was described in previous studies (Parisi et al., 2019; Swatschek et al., 2002; Fernandes et al., 2019). In short, after collection, the Aplysina fulva were cut in small pieces and were washed three times in Milli-Q water. Samples were mixed with Tris-HCl buffer (100 mM, pH 9.5, 10 mM EDTA, 8 M urea, $100 \mathrm{mM}$ 2-mercaptoethanol) and had the $\mathrm{pH}$ adjusted to 9 (with the addition of $\mathrm{NaOH}$ ). The solution was kept in agitation for $24 \mathrm{hrs}$. Afterwards, solution was centrifuged for 5 mins $(2 \mathrm{oC})$, the supernatant removed and the pellet was discarded. The $\mathrm{pH}$ was adjusted again, to 4 (using acetic acid solution) and a precipitate was acquired, which was resuspended in Milli-Q water, centrifuged again and lyophilized for preservation (Swatschek et al., 2002).

Scaffold preparation: Porous scaffolds (60\%) with two different formulations, were used in this study: SPG (20\%) and BS $100 \%$ and BS (80\%). For the scaffold preparation, carboxymethyl cellulose (CMC) (Sigma Aldrich, Missouri) and methyl methacrylate (MMA, purity: 99.09\%) (VIPI Produtos Odontológicos, Pirassununga, São Paulo, Brazil) were employed (Sousa et al., 2008; Lopez-Heredia et al., 2012; Haach et al., 2014). Table 1 shows the weights of the materials for the manufacturing, 
the samples are inserted in a container with distilled water and mixed with a spatula. After that, MMA was added as an aggregating agent, solution was mixed again and the resulting paste was transferred to a silicon mold, with de dimensions of 8 $\mathrm{mm} \times 2 \mathrm{~mm}$. CMC was mixture and the molds were sealed, submitted to a pressure air chamber (at $0.6 \mathrm{MPa}$ ) for 30 mins and vacuum dried (10-3 Torr) for 15 mins. The composites were removed from the silicon molds, packaged and sterilized by ethylene oxide (Acecil, Campinas, SP, Brazil). This method is known for its safety and for not affecting the characteristics of the material (Fernandes et al., 2019).

Table 1: Experimental formulations of composites expressed in grams (g).

\begin{tabular}{ccccccc}
\hline Groups & PMMA(g) & MMA(g) & BS(g) & SPG(g) & CMC(g) & Water(g) \\
\hline BS & 0.236 & 0.472 & 0.560 & 0 & 0.043 & 0.565 \\
BS/SPG 80/20 & 0.236 & 0.472 & 0.368 & 0.092 & 0.043 & 0.565 \\
\hline
\end{tabular}

Source: Authors (2021).

\subsection{In vivo studies}

Twelve weeks Wistar rats ( $\mathrm{n}=36$ ), weighting 300-350 g, were used in the study and distributed into 3 groups ( $\mathrm{n}=12$ per group): group 1 (G1): animals with a cranial bone defect irradiated with PBM; group 2 (G2): BS treated bone defects irradiated with PBM and group 3 (G3): BS/SPG treated defects irradiated with PBM. Two sub-groups were created ( $\mathrm{n}=6$ per subgroup), with different times of euthanasia (15 and 45 days). Animals were maintained under the temperature of $22 \pm 2^{\circ} \mathrm{C}$, in a light-dark cycle of 12 hours and with standard food free access and water. This present study was approved by the Animal Care Committee of the Federal University of São Paulo (CEUA n ${ }^{\circ}$ 4331220318). All the Ethical methods and guidelines of animal wellbeing were followed.

Surgical procedure: for the cranial bone defect induction, all animals were firstly submitted to anesthesia (ketamine (80 $\mathrm{mg} / \mathrm{kg})$, acepromazine $(1 \mathrm{mg} / \mathrm{kg})$, xylazine $(8 \mathrm{mg} / \mathrm{kg})$ and fentanyl $(0.05 \mathrm{mg} / \mathrm{kg})$. Animals were then immobilized and had their skulls shaved and disinfected. A skin incision was performed to access the calvaria bone tissue and, with using trephine drill (3i Implant Innovations Inc., Palm Beach Gardens, USA) under copious saline irrigation, a $8 \mathrm{~mm}$ defect was created in the parietal region (Luvizuto et al., 2012; Kubota et al., 2017). Samples were then implanted according to the randomization scheme and the wounds were closed with resorbable Vicryl® 5-0 (Johnson \& Johnson, St.Stevens-Woluwe, Belgium). Appropriate postoperative animal cares were given and animals were monitored for signs of infection, pain and proper activity. Animals were kept in cages (4 per cage) and the intake of water and food was monitored in the initial post-operative period. The method of $\mathrm{CO} 2$ suffocation was used for euthanasia, after the experimental periods.

\subsection{PBM treatment}

PBM treatment was performed using the equipment Photon Lase III (DMC, São Carlos, Brazil) in the parameters described in Table 2. Irradiation was performed at a single point in the center of the bone defect. A total of 6 and 18 sessions (depending on the group) ( 3 applications per week, in non-consecutive days) were made. PBM parameters were chosen based on a previous works (Bossini et al., 2012; Fernandes et al., 2017b; Pinto et al., 2013; Fangel et al., 2011). 
Table 2: Photobiomodulation parameters

\begin{tabular}{cc}
\hline Parameters & Values \\
\hline Power & $30 \mathrm{mw}$ \\
Wavelength & $808 \mathrm{~nm}$ (infrared) \\
Mode of action & Continuous \\
Beam transverse area & $0.028 \mathrm{~cm}^{2}$ \\
Energy density & $30 \mathrm{~J} / \mathrm{cm}^{2}$ \\
Time & $28 \mathrm{~s}$ \\
Energy & $0.8 \mathrm{~J}$ \\
Application mode & Stationary in skin contact mode \\
\hline
\end{tabular}

Source: Authors (2021).

\subsection{Histological procedures}

Samples were retrieved and fixed for $24 \mathrm{~h}$ in formaldehyde, followed by dehydration (in ethanol) and embedding in methyl methacrylate (MMA). The calcified samples were then cut in a perpendicular direction, to the medial-lateral drilling axis of the implants using a microtome with a tungsten carbide disposable blade (Leica TC65, Leica Microsystems SP 1600, Nussloch, Germany). Cuts of $5 \mu \mathrm{m}$ was used to obtain the laminaes which were stained with Goldner Trichrome (three sections of each specimen). A light microscopy (Leica Microsystems AG, Wetzlar, Germany) was used for analysis. A qualitative analysis was performed considering the following parameters: granulation tissue, newly formed bone, osteoides and particles of biomaterial. The analysis was performed by 2 experienced pathologists (G.C.A.V and J.R.P.), in a blind way.

\subsection{Histomorphometric analysis}

OsteoMeasure System software (Osteometrics, Atlanta, GA, USA) was used for the quantitative analysis of the samples. Area analyzed for each laminae was $2.879 \pm 0.674 \mathrm{~mm} 2$, which covered all the regions of the bone defect. The following variables were obtained: bone volume as a percentage of tissue volume (BV/TV, \%), osteoid volume as a percentage of tissue volume (OV/TV, \%), number of osteoblasts per unit of tissue area (N.Ob/T.Ar, /mm2) and osteoblast surface as a percentage of bone surface (OB.S/BS, \%). Histomorphometric analysis was made by one experienced observer (G.C.A.V.), in a blinded way.

\subsection{Immunohistochemistry analysis}

For immunohistochemistry analysis, the streptavidin-biotin-peroxidase method was used. Resin was removed from the samples and they were submitted to the dehydration in ethanol and pretreated with $0.01 \mathrm{M}$ citric acid buffer (pH 6) (5 mins in a steamer). Endogenous peroxidase was inactivated using hydrogen peroxide in phosphate-buffered saline (PBS) for 5 min and with 5\% normal goat serum in PBS (10 mins). Antibodies were incubated with anti-vascular endothelial growth factor (antiVEGF, Santa Cruz Biotechnology, USA, concentration of 1:200) and anti-transforming growth factor beta (anti-TGF-b, Santa Cruz Biotechnology, USA, at a concentration of 1:200), for 2 h. Secondary antibody anti-rabbit IgG (Vector Laboratories, Burlingame, CA, USA) was added and samples were incubated (avidin biotin complex conjugated to peroxidase) for 30 min. 3 3'-diaminobenzidine solution was used for immunostaining ( $5 \mathrm{~min}$ ) and restained with Harris haematoxylin (Merck) for 4 min. The location and presence of the immunomarkers were qualitatively performed using a light microscopy (Leica Microsystems AG, Wetzlar, Germany). In addition, a semi-quantitative analysis was also performed using the score: $1=$ absent $(0 \%$ of immunostaining), $2=$ weak $(1-25 \%$ of immunostaining $), 3=$ moderate $(36-67 \%$ of immunostaining $)$ and $4=$ intense $(68-$ 
100\% of immunostaining) (Fernandes et al., 2017a). All the evaluation was performed in a blinded way (G.C.A.V. and J.R.P.).

\subsection{Statistical analysis}

In the statistical analysis, the distribution of variables was tested using the Shapiro-Wilk normality test. For the analysis of multiple comparisons, ANOVA was used with post hoc Tukey for parametric data and nonparametric data, the Kruskal-Wallis test was used with post hoc Dunn. Data were analysed and displayed in graphs and expressed as standard deviation and mean. The level of significance was set at $5 \%(\mathrm{p} \leq 0.05)$. All statistical analyses were performed using the software GraphPad Prism (version 6.01).

\section{Results}

\subsection{Histological analysis}

Figure 1 demonstrates the photomicrographies of the qualitative analysis for all experimental groups (15 and 45 after surgery).

Figure 1: Representative histological sections of cranial bone defects of the groups: G1 (A, D); G2 (B, E); G3 (C, F) after fifteen and forty-five days after surgery, respectively. Newly formed bone (NB), granulation tissue (GT), osteoid (*), residual material (black arrow). Bar represents $100 \mu \mathrm{m}$. (mag. X20).

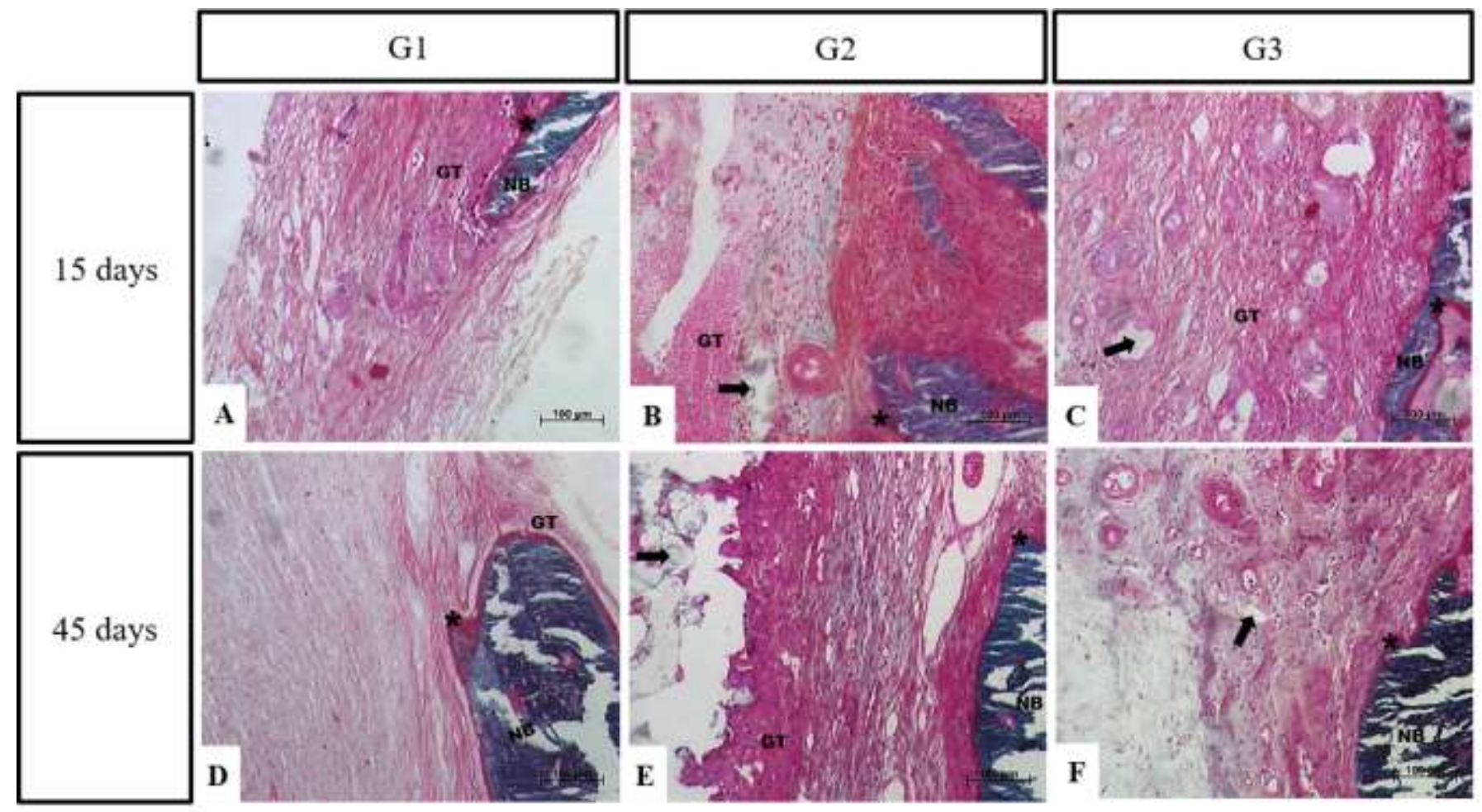

Source: Authors (2021).

Fifteen days post-surgery, for G1, bone defect was filled mainly with granulation tissue. Moreover, newly formed bone, with some areas of osteoid tissue, was presented (Figure 1A). For G2, most of the defect was filled with granulation tissue, biomaterial particles, some areas of newly formed bone and osteoid (Figure 1B). Newly formed bone and osteoid were abundantly seen for animals of G3. Additionally, biomaterial particles, surrounded by granulation tissue, were observed in these animals (Figure 1C). 
Forty-five days after surgery, an increased amount of osteoid and newly formed bone were seen through the defect area compared to the first experimental period for G1 (Figure 1D). Furthermore, remaining areas of granulation still could be observed in the center (Figure 1D). Similar histological findings were observed for G2 (Figure 1E) and G3 (Figure 1F), with few particles of biomaterial and newly formed bone (with a more mature aspect) and osteoid filling most of the defect. Moreover, scarce areas of granulation tissue at the center were observed.

\subsection{Histomorphometric analysis}

Figure 2 demonstrates the histomorphometric analysis for all experimental groups (fifteen and forty-five days after surgery).

Figure 2: Bone volume as a percentage of tissue volume BV/TV \% (A), osteoid volume as a percentage of tissue volume OV/TV \% (B), osteoid thickness O.Th, $\mu \mathrm{m}$ (C), number of osteoblasts per unit of tissue area N.Ob/T.Ar, mm2 (D) and osteoblastic surface as a percentage of bone surface Ob.S/BS \% (E). for G1, G2 and G3 after fifteen and forty-five days after surgery. Dunn's test. ${ }^{*} \mathrm{p}<0.05 * * \mathrm{p}<0.01$.

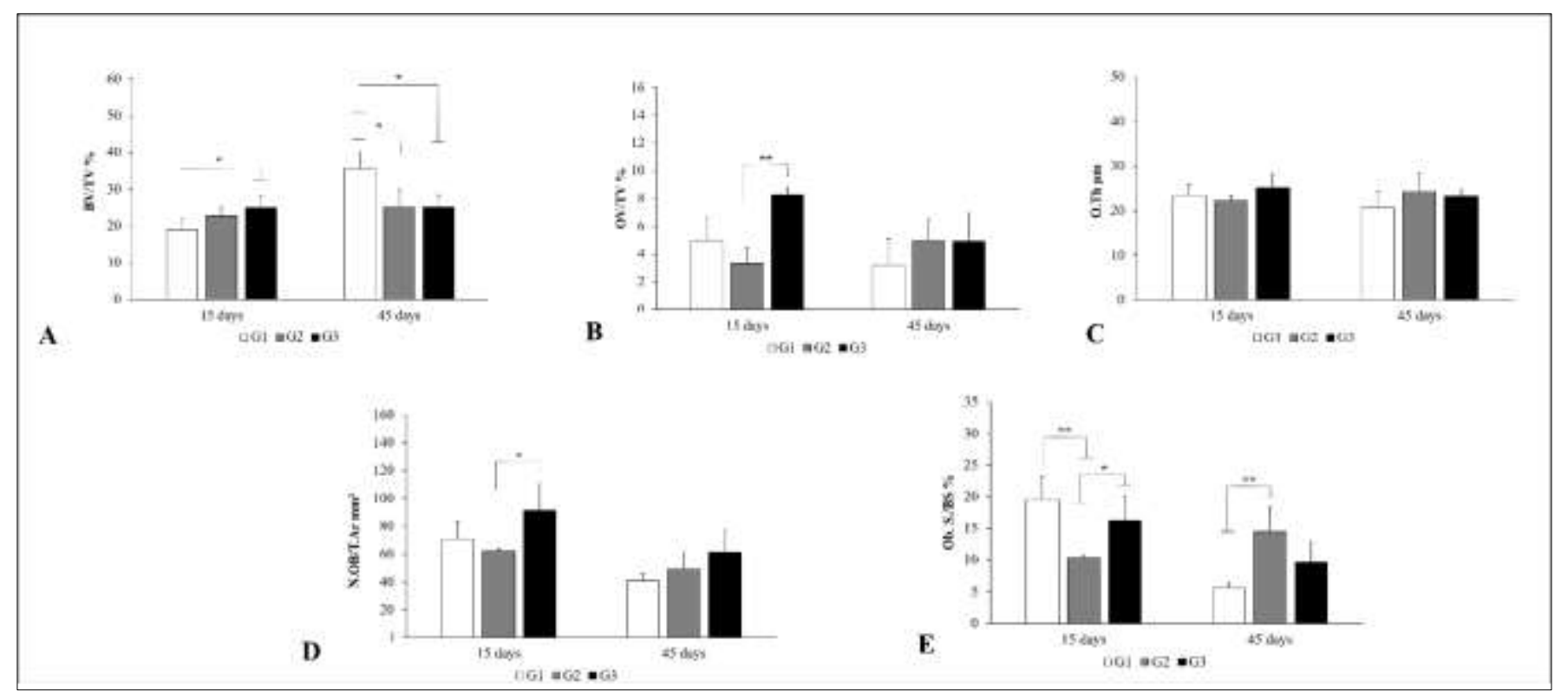

Source: Authors (2021).

Figure 2A demonstrates higher mean values for BV/TV\% in G3 compared to G1 ( $\mathrm{p}=0.0175)$ in the first experimental period analyzed. Interestingly, forty-five days after surgery higher values for G1 were observed compared to the 2 other groups. No other difference was found.

Figure 2B demonstrated a higher mean value of OV/TV (\%) for G3 compared to G2 in the first experimental period analyzed $(p=0.0020)$. No other difference was observed. In addition, the variable O.th $(\mu \mathrm{m})$ demonstrated that no statistically difference was found among groups, for both experimental periods (Figure 2C).

Figure 2D demonstrated that, for N.Ob/T.Ar (mm2), significant higher values were found for $\mathrm{G} 3$ compared to $\mathrm{G} 2$ in the first experimental period $(\mathrm{p}=0.0142)$. No other statistically difference was observed. For Ob.S/BS (\%), significant higher values could be seen in G1 and G3 in comparison to G2, in the first experimental period (Figure 2E). Forty-five days after surgery, significantly higher values were observed for $\mathrm{G} 2$ compared to $\mathrm{G} 1$ ( $\mathrm{p}=0.0016$ ) (Figure 2E). 


\subsection{Immunohistochemistry analysis}

\section{TGF-b immunostaining}

The qualitative immunohistochemistry analysis of TGF-b for all experimental groups, fifteen and forty-five days after surgery is represented in Figure 3.

Figure 3: Representative histological sections of Transform Growth Factor Beta (TGF - $\beta$ ) immunohistochemistry of the G1, G2 and G3 experimental groups, after fifteen and forty-five days after surgery. TGF-b immunostaining $(\mathbf{\Lambda})$ and biomaterial $(*)$. Scale bar: $100 \mu \mathrm{m}$ (mag. X20).

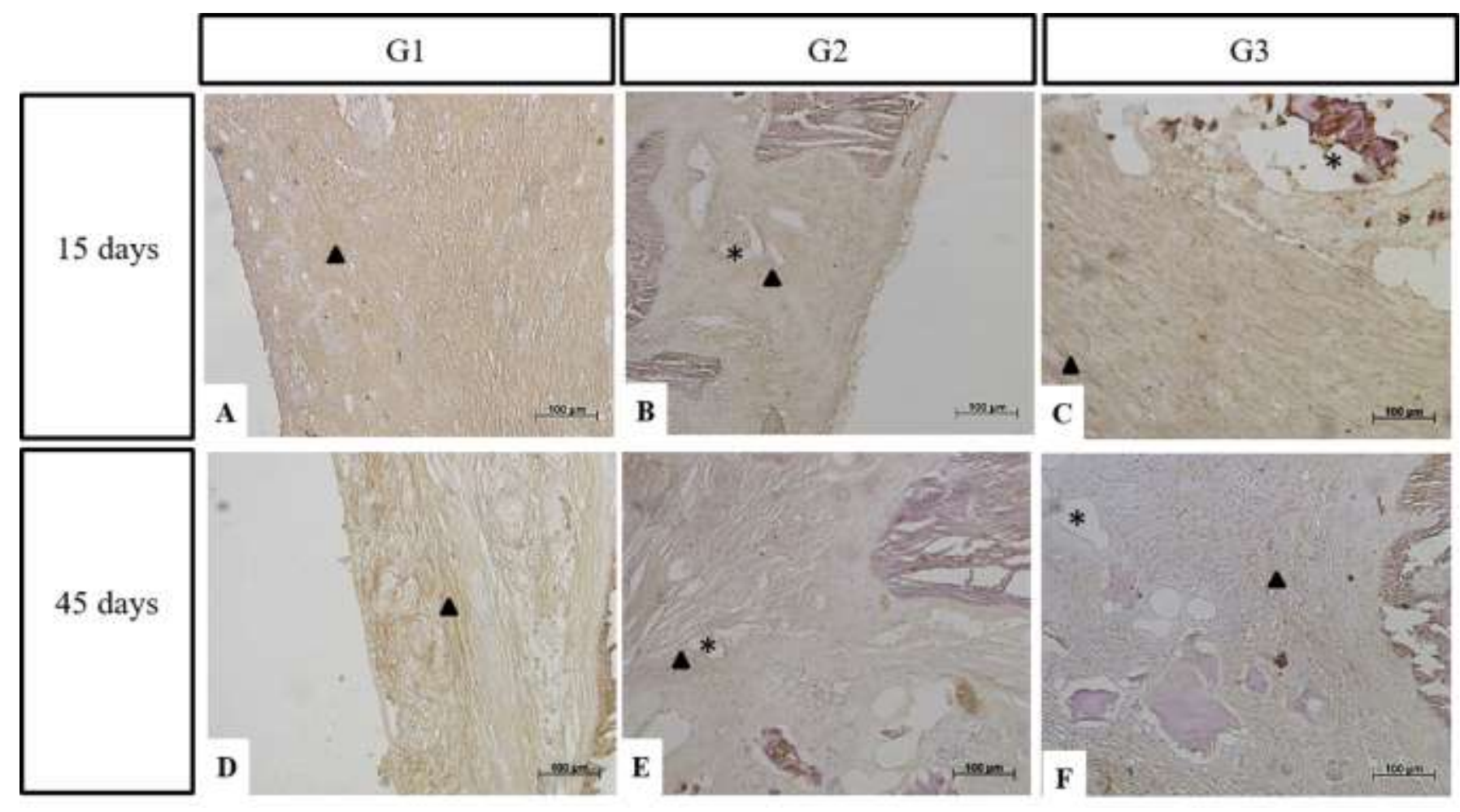

Source: Authors (2021).

For both experimental periods, TGF-b immunostaining was observed in the granulation tissue in G1 (Figure 3A and 3D). For G2 and G3 groups, TGF-b immunostaining was verified around the particles of the materials into the area of the bone defect and in granulation tissue, after fifteen and forty-five days after surgery (Figure 3B, 3C, 3E and 3F).

The semi-quantitative analysis of TGF- $\beta$ immunostaining after fifteen and forty-five days after surgery, is shown in Figure 4A. 
Figure 4: Means and standard deviation of immunohistochemistry scores: TGF- $\beta(A)$ and VEGF(B). ${ }^{*} p<0.05$.

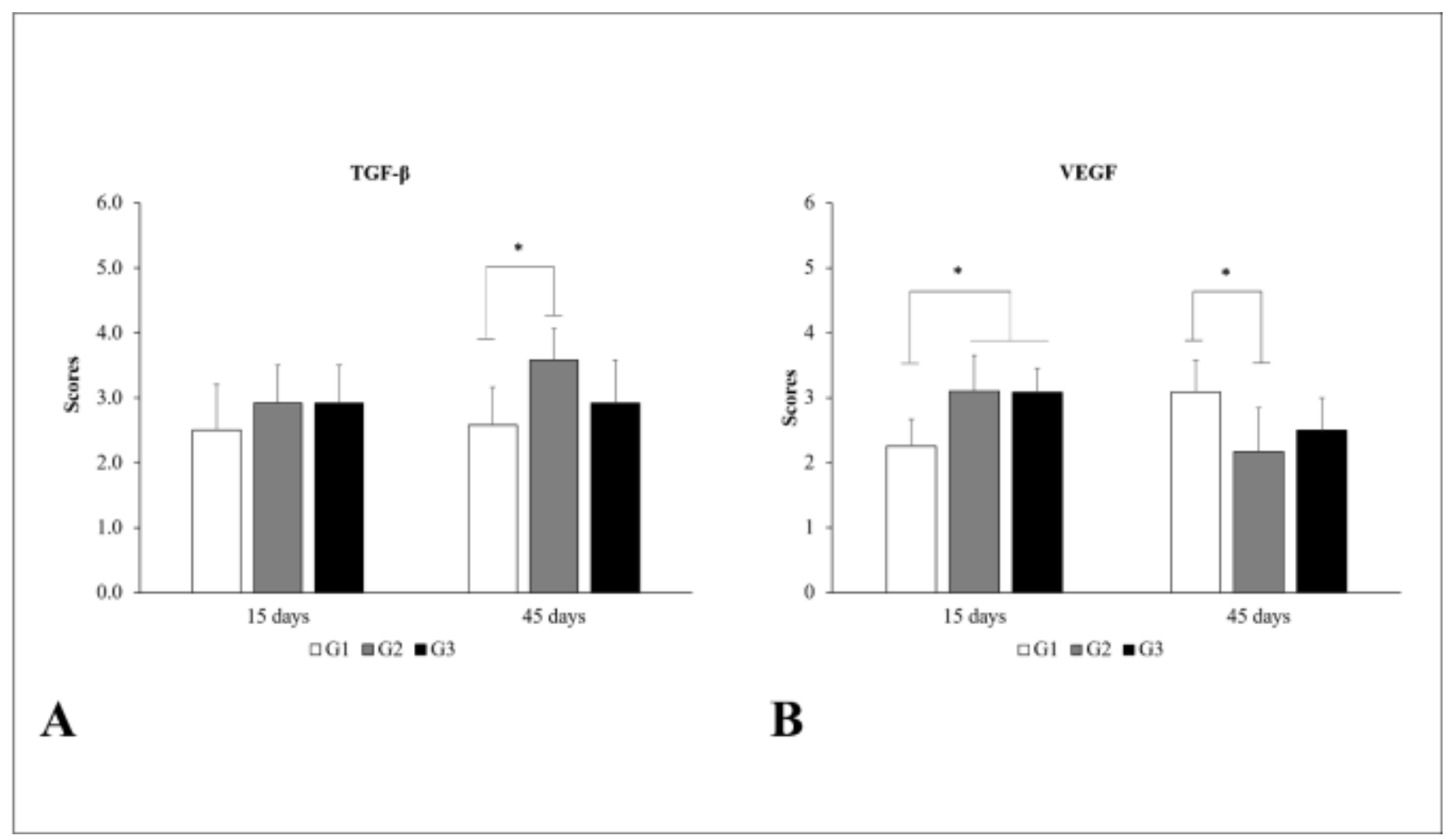

Source: Authors (2021).

No significant difference among any experimental groups was observed in the first period analyzed. Furthermore, after 45 days after surgery, it is possible to observe a significantly higher immunolabelling of TGF- $\beta$ for G2 compared to G1 ( $p=$ $0.0387)$.

\section{VEGF immunostaining}

Figure 5 represents the qualitative immunohistochemistry analysis of VEGF for all the experimental groups, fifteen and forty-five days after surgery. 
Figure 5: Representative histological sections of VEGF immunohistochemistry for G1, G2 and G3, fifteen and forty-five days after surgery. Biomaterial $(*)$ and VEGF immunostaining $(\mathbf{\Lambda})$. Scale bar: $100 \mu \mathrm{m}(\mathrm{mag} . \mathrm{X} 20)$.

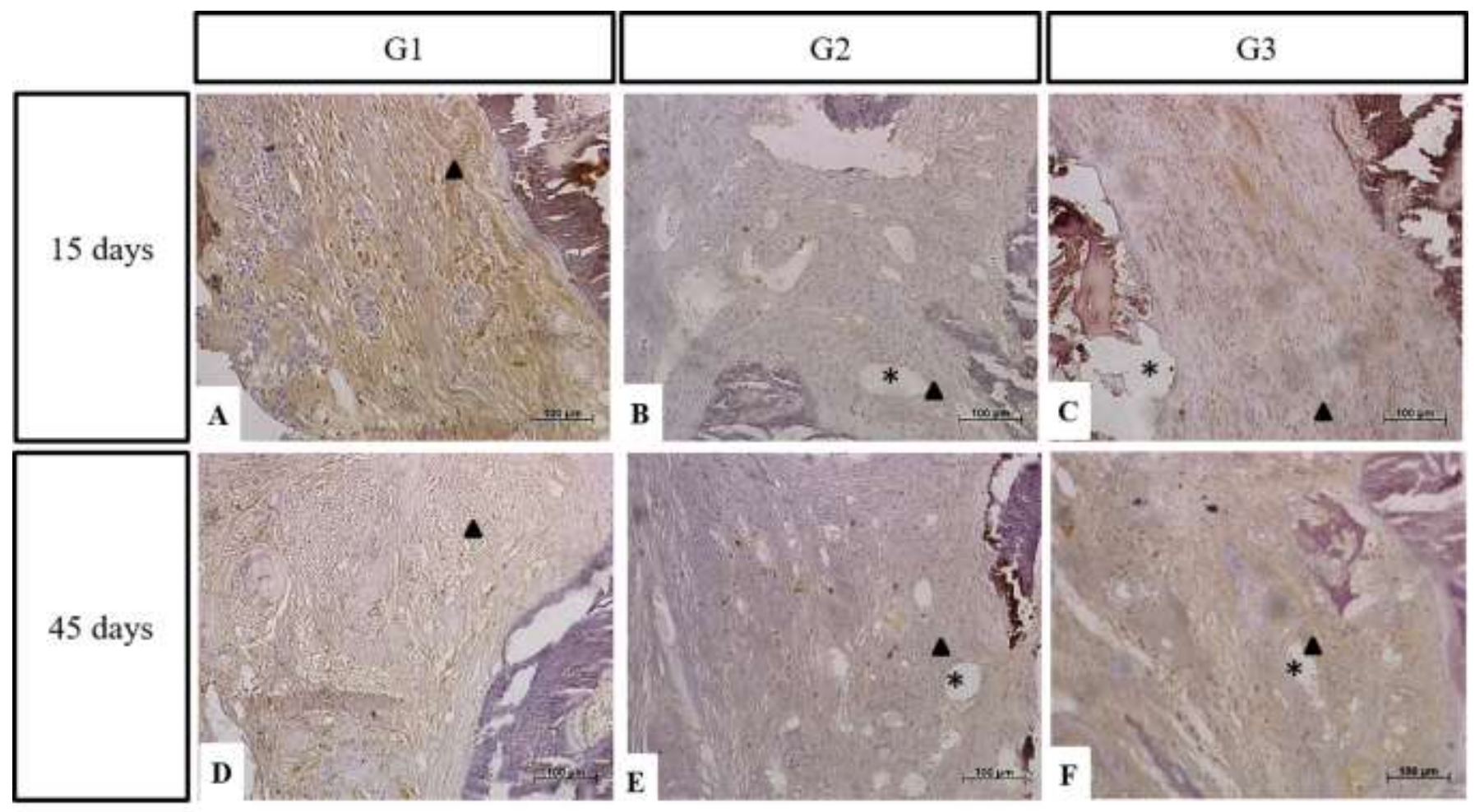

Source: Authors (2021).

In both periods analyzed we can observe, that VEGF immunostaining was observed in the granulation and connective tissue present along bone defect for G1 (Figure 5A and Figure 5D). For G2 and G3, VEGF immunostaining was verified around the particles of the materials and in granulation tissue, after fifteen and forty-five days after surgery (Figure 5B and Figure 5C). Furthermore, similar findings were also observed for both groups (G2 and G3) after forty-five days after surgery, with VEGF immunostaining being seen in granulation tissue and around the particles of the materials in the center of the defect (Figure 5E and Figure 5F).

Figure 4B presents the semi-quantitative analysis of VEGF immunostaining after fifteen and forty-five days after surgery. At fifteen days post-surgery, a significantly higher value was observed for G2 and G3 compared to G1 ( $\mathrm{p}=0.0498$ and $\mathrm{p}=0.0468$, respectively). Additionally, forty-five days after surgery, it was possible to observe a significantly higher immunolabeling of VEGF expression for G1 compared to $\mathrm{G} 2(\mathrm{p}=0.0387)$.

\section{Discussion}

The study investigated the introduction of SPG into BS and their association of PBM on healing of a critical cranial bone defect in rats. Histological analysis demonstrated that the associated treatment presented an increased amount of newly formed over time. Moreover, histomorphometry showed values for BV/TV for G3 and G1 higher, fifteen and forty-five days after surgery (respectively). For OV/TV (\%) and N.Ob/T.Ar (mm2) higher values were observed for G3 compared to G2 in the first experimental period. Furthermore, for Ob.S/BS (\%), G2 exhibited lower values at day 15, but higher values forty-five days after surgery. TGF- $\beta$ immunolabelling was higher for G2, forty-five days after surgery. The values found for VEGF were higher for BS (with or without SPG) in the first experimental period with an increased difference being observed for G1, forty-five days after surgery. 
PBM is a very promising intervention able of stimulating bone ingrowth and fracture healing (Tim et al., 2015; Magri et al., 2015; Sarvestani et al., 2017). The effects of PBM are positive on the process of bone healing, this is attributed to the fact that PBM was able of stimulating mesenchymal cells and osteoblasts, culminating in the increase of newly formed bone deposition (Santinoni et al., 2017; Noba et al., 2018; Skondra et al., 2018). Shakouri et al., (2010) showed that PBM enhanced the callus development in the early stage of the healing process in rabbits, with improvement in the biomechanical properties of bone healing. Furthermore, it has been reported that the association of PBM and BS also has stimulatory effects on newly bone deposition and neovascularization by stimulating the secretion of angiogenic factors, which together with the osteopromotive properties of both therapeutical interventions positively influence the acceleration of bone repair (Fangel et al., 2014; Bossini et al., 2011).

Moreover, some authors demonstrated the stimulatory effects of BS and Col (including the ones with SPG) composites on bone tissue metabolism (Fernandes et al., 2017b; Kido et al., 2017; Matsumoto et al., 2012). In the study, composite (BS/SPG) scaffolds allowed higher bone formation after 15 days but, despite the histological findings demonstrate that BS scaffolds (with or without SPG) degraded over time, the biomaterial presence inside the defect may have constituted a physical barrier for the tissue ingrowth at the latest time point. This fact can be the explanation for the result found at day 45 , for the higher values of bone volume in G1, which is the only group where defects were not scaffold-filled. On the other hand, despite no differences concerning osteoid volumes at this later time point, the percentage of bone surface recovered by active bone-forming cells was higher in defects filled with BS scaffolds, which may indicate that a new bone increment may happen in a future (not-evaluated) period in this group.

Also, it is important to emphasize that no inflammatory response was observed in the biomaterial treated animals, indicating the biocompatibility of BS and SPG. It is well known that ionic dissolution products of BS have been shown to beneficially affect osteogenesis by formation of a silica rich layer which acts as a template for calcium phosphate precipitation and directs new bone formation (Granito et al., 2011; Hench \& Polak, 2002). Furthermore, combining materials with the aim of obtaining bone biomimetic materials (for example, BS and Col) may be a very promising strategy for bone tissue engineering proposals. Composites mimicking bone composition such as the association of Col (representing the organic part) with BG (the inorganic part) have been demonstrating improved biological properties in the process of bone healing (Parisi et al., 2019; Fernandes et al., 2019; Ueno et al., 2016). In the study, the addition of SPG (at the percentage of 20\%) could accelerate bone tissue deposition. Instead of the fact that no significant differences were seen at the later time point after surgery, histomorphometric values for bone and osteoid volumes, as well as osteoblast number and surface, were higher at the earlier period when the composite BS/SPG were implanted in PBM irradiated animals.

In addition, TGF $\beta$ plays an important function in bone remodeling, stimulating the synthesis of matrix protein and proliferation of osteoblasts ( $\mathrm{Wu}$ et al., 2016). The higher immunolabeling for TGF $\beta$ observed for PBM/BS treated animals demonstrated the possible influence of this therapy on the proliferation of osteoblast cells, which may culminate in the increase of newly formed bone deposition (Guo et al., 2018). Demonstrated that bioactive glass nanoparticles were able of efficiently activate the TGF- $\beta$ signaling pathway and enhance the osteogenic differentiation of stem cells (Guo et al., 2018). Mokoena et al., (2018), in a review, demonstrated that PBM is also able of stimulating TGF $\beta$ labeling.

Moreover, for a proper healing process an adequate vascularization is necessary and VEGF is the main mediator for the formation of newly blood vessels formation (Johnson \& Wilgus, 2014). In the study, PBM/BS (with or without SPG) treated animals presented a higher VEGF immunolabelling fifteen days after surgery but PBM irradiated animals presented a higher expression on day forty-five after surgery. It has been reported that PBM and BG have stimulatory effects on neovascularization by stimulating the secretion of angiogenic factors (Gabbai-armelin et al., 2015; Granito et al., 2009; Fernandes et al., 2019; Hench \& Polak, 2002; Cury et al., 2013). This point associated to the osteopromotive properties of PBM and BG might early 
influence bone formation. Furthermore, D’Mello et al., (2015), using a biomimetic material (containing col), observed a positive immunostaining for VEGF factor in a defect of rat calvaria. In this context, it is possible to suggest that both BS and PBM had a positive influence in VEGF immunolabeling, which may have influenced in the newly formed bone deposition. Interestingly, for both VEGF and TGF $\beta$, the introduction of SPG did not have any extra effect.

Biomaterials with different compositions and structure have been extensively studied for bone tissue engineering proposals. In this context, a composite material, including BS enriched with a newly marine Col was studied (Parisi et al., 2020). Indeed, the introduction of SPG into BS and the association with PBM induced a more appropriate response to stimulate bone metabolism, especially in the beginning of the repair. Furthermore, the data of the study highlight the huge biological potential of SPG to be used as the organic part to improve the performance of bone grafts. As the study was limited to relatively shortterm evaluation of the effects of the composites and PBM, detailed information on the long-term performance remains to be provided. Following this line, further investigations are necessary in order to validate these combinations as safe and efficient materials for biomedical applications with the aim of applying the therapeutical interventions in clinical trials.

\section{Conclusion}

In conclusion, the stimulus provided by PBM associated to the biomimetic composite increased bone formation in the cranial bone defect in rats. Consequently, these data highlight the potential of the introduction of SPG into BS and irradiated with PBM to improve the biological performance for bone regeneration applications. However, further studies should be carried out to investigate the material degradation and bone regeneration induced in late stages by BS/SPG and PBM.

\section{Acknowledgments}

Authors would like to thank Fundação de Amparo à Pesquisa do Estado de São Paulo (FAPESP) for the scholarship (grant no. 2016/13636-9).

\section{References}

Bossini, P. S., Rennó, A. C. M., Ribeiro, D. A., Fangel, R., Peitl, O., Zanotto, E. D., \& Parizotto, N. A. (2011). Biosilicate® and low-level laser therapy improve bone repair in osteoporotic rats. Journal of Tissue Engineering and Regenerative Medicine, 12:52-57. https://doi.org/10.1002/term.309

Bossini, P. S., Rennó, A.C., Ribeiro, D. A., Fangel, R., Ribeiro, A. C., Lahoz, M. A., \& Parizotto, N. A. (2012). Low level laser therapy (830nm) improves bone repair in osteoporotic rats: similar outcomes at two different dosages. Experimental Gerontology, 47:136-42. https://doi.org/10.1016/j.exger.2011.11.005

Cury, V., Moretti, A. I., Assis, L., Bossini, P., Crusca, J. S., Neto, C. B., Fangel, R., Souza, H. P., Hamblin, M. R., \& Parizotto, N. A. (2013). Low level laser therapy increases angiogenesis in a model of ischemic skin flap in rats mediated by VEGF, HIF-1 $\alpha$ and MMP-2. Journal of photochemistry and photobiology. B, Biology, 125:164-170. https://doi.org/10.1016/j.jphotobiol.2013.06.004

D'Mello, S. R., Elangovan, S., Hong, L., Ross, R. D., Sumner, D. R., \& Salem, A. K. (2015). A Pilot Study Evaluating Combinatorial and Simultaneous Delivery of Polyethylenimine-Plasmid DNA Complexes Encoding for VEGF and PDGF for Bone Regeneration in Calvarial Bone Defects. Current pharmaceutical biotechnology, 16(7), 655-660. https://doi.org/10.2174/138920101607150427112753

de Freitas, L. F., \& Hamblin, M. R. (2016). Proposed Mechanisms of Photobiomodulation or Low-Level Light Therapy. IEEE journal of selected topics in quantum electronics : a publication of the IEEE Lasers and Electro-optics Society, 22(3), 7000417. https://doi.org/10.1109/JSTQE.2016.2561201

Einhorn, T. A., \& Gerstenfeld, L. C. (2015). Fracture healing: mechanisms and interventions. Nature reviews. Rheumatology, 11(1), 45-54. https://doi.org/10.1038/nrrheum.2014.164

Exposito, J. Y., Cluzel, C., Garrone, R., \& Lethias, C. (2002). Evolution of collagens. The Anatomical record, 268(3), 302-316. https://doi.org/10.1002/ar.10162

Fangel, R., Bossini, P. S., Renno, A. C., Ribeiro, D. A., Wang, C. C., Toma, R. L., Nonaka, K. O., Driusso, P., Parizotto, N. A., \& Oishi, J. (2011). Low-level laser therapy, at $60 \mathrm{~J} / \mathrm{cm} 2$ associated with a Biosilicate(®) increase in bone deposition and indentation biomechanical properties of callus in osteopenic rats. Journal of biomedical optics, 16(7), 078001. https://doi.org/10.1117/1.3598847

Fangel, R., Bossini, P. S., Renno, A. C., Granito, R. N., Wang, C. C., Nonaka, K. O., Driusso, P., Parizotto, N. A., \& Oishi, J. (2014). Biomechanical properties: effects of low-level laser therapy and Biosilicate ${ }^{\circledR}$ on tibial bone defects in osteopenic rats. Journal of applied biomaterials \& functional materials, $12(3), 271-$ 277. https://doi.org/10.5301/jabfm.5000198 
Farivar, S., Malekshahabi, T., \& Shiari, R. (2014). Biological effects of low level laser therapy. Journal of lasers in medical sciences, 5(2), 58-62.

Fernandes, K. R., Ribeiro, D. A., Rodrigues, N. C., Tim, C., Santos, A. A., Parizotto, N. A., de Araujo, H. S., Driusso, P., \& Rennó, A. C. (2013). Effects of low-level laser therapy on the expression of osteogenic genes related in the initial stages of bone defects in rats. Journal of biomedical optics, 18(3), 038002. https://doi.org/10.1117/1.JBO.18.3.038002

Fernandes, K. R., Magri, A., Kido, H. W., Ueno, F., Assis, L., Fernandes, K., Mesquita-Ferrari, R. A., Martins, V. C., Plepis, A. M., Zanotto, E. D., Peitl, O., Ribeiro, D., van den Beucken, J. J., \& Renno, A. (2017a). Characterization and biological evaluation of the introduction of PLGA into biosilicate ${ }^{\circ}$. Journal of biomedical materials research. Part B, Applied biomaterials, 105(5), 1063-1074. https://doi.org/10.1002/jbm.b.33654

Fernandes, K. R., Magri, A., Kido, H. W., Parisi, J. R., Assis, L., Fernandes, K., Mesquita-Ferrari, R. A., Martins, V. C., Plepis, A. M., Zanotto, E. D., Peitl, O., \& Renno, A. (2017b). Biosilicate/PLGA osteogenic effects modulated by laser therapy: In vitro and in vivo studies. Journal of photochemistry and photobiology. B, Biology, 173, 258-265. https://doi.org/10.1016/j.jphotobiol.2017.06.002

Fernandes, K. R., Parisi, J. R., Magri, A., Kido, H. W., Gabbai-Armelin, P. R., Fortulan, C. A., Zanotto, E. D., Peitl, O., Granito, R. N., \& Renno, A. (2019). Influence of the incorporation of marine spongin into a Biosilicate ${ }^{\circ}$ : an in vitro study. Journal of materials science. Materials in medicine, 30(6), 64. https://doi.org/10.1007/s10856-019-6266-2

Fortuna, T., Gonzalez, A. C., Sá, M. F., Andrade, Z. A., Reis, S., \& Medrado, A. (2018). Effect of 670 nm laser photobiomodulation on vascular density and fibroplasia in late stages of tissue repair. International wound journal, 15(2), 274-282. https://doi.org/10.1111/iwj.12861

Gabbai-Armelin, P. R., Souza, M. T., Kido, H. W., Tim, C. R., Bossini, P. S., Magri, A. M., Fernandes, K. R., Pastor, F. A., Zanotto, E. D., Parizotto, N. A., Peitl, O., \& Renno, A. C. (2015). Effect of a new bioactive fibrous glassy scaffold on bone repair. Journal of materials science. Materials in medicine, 26(5), 177. https://doi.org/10.1007/s10856-015-5516-1

Gabbai-Armelin, P. R., Souza, M. T., Kido, H. W., Tim, C. R., Bossini, P. S., Fernandes, K. R., Magri, A. M., Parizotto, N. A., Fernandes, K. P., MesquitaFerrari, R. A., Ribeiro, D. A., Zanotto, E. D., Peitl, O., \& Renno, A. C. (2017). Characterization and biocompatibility of a fibrous glassy scaffold. Journal of tissue engineering and regenerative medicine, 11(4), 1141-1151. https://doi.org/10.1002/term.2017

Granito, R. N., Ribeiro, D. A., Rennó, A. C., Ravagnani, C., Bossini, P. S., Peitl-Filho, O., Zanotto, E. D., Parizotto, N. A., \& Oishi, J. (2009). Effects of biosilicate and bioglass $45 \mathrm{~S} 5$ on tibial bone consolidation on rats: a biomechanical and a histological study. Journal of materials science. Materials in medicine, 20(12), 2521-2526. https://doi.org/10.1007/s10856-009-3824-z

Granito, R. N., Rennó, A. C., Ravagnani, C., Bossini, P. S., Mochiuti, D., Jorgetti, V., Driusso, P., Peitl, O., Zanotto, E. D., Parizotto, N. A., \& Oishi, J. (2011). In vivo biological performance of a novel highly bioactive glass-ceramic (Biosilicate $\left.{ }^{\circledR}\right)$ : A biomechanical and histomorphometric study in rat tibial defects. Journal of biomedical materials research. Part B, Applied biomaterials, 97(1), 139-147. https://doi.org/10.1002/jbm.b.31795

Green, D., Howard, D., Yang, X., Kelly, M., \& Oreffo, R. O. (2003). Natural marine sponge fiber skeleton: a biomimetic scaffold for human osteoprogenitor cell attachment, growth, and differentiation. Tissue engineering, 9(6), 1159-1166. https://doi.org/10.1089/10763270360728062

Guo, Y., Xue, Y., Niu, W., Chen, M., Wang, M., Ma, P. X., \& Lei, B. (2018). Monodispersed Bioactive Glass Nanoparticles Enhance the Osteogenic Differentiation of Adipose-Derived Stem Cells through Activating TGF-Beta/Smad3 Signaling Pathway. Particle \& Particle Systems Characterization, 35(7), 1800087. https://doi.org/10.1002/ppsc.201800087

Haach, L. C. A., Purquerio, B. M., Silva Jr, N. F., Gaspar, A. M. M., \& Fortulan, C. A. (2014). Comparison of Two Composites Developed to be Used as Bone Replacement - PMMA/Bioglass 45S5® Microfiber and PMMA/ Hydroxyapatite. Bioceramics Development and Applications, 4:071. https://doi.org/10.4172/2090-5025.1000071

Hamblin M. R. (2017). Mechanisms and applications of the anti-inflammatory effects of photobiomodulation. AIMS biophysics, 4(3), 337-361. https://doi.org/10.3934/biophy.2017.3.337

Hench, L. L., \& Polak, J. M. (2002). Third-generation biomedical materials. Science (New York, N.Y.), 295(5557), 1014-1017. https://doi.org/10.1126/science.1067404

Iwatsubo, T., Kishi, R., Miura, T., Ohzono, T., \& Yamaguchi, T. (2015). Formation of Hydroxyapatite Skeletal Materials from Hydrogel Matrices via Artificial Biomineralization. The journal of physical chemistry. B, 119(28), 8793-8799. https://doi.org/10.1021/acs.jpcb.5b03181

Johnson, K. E., \& Wilgus, T. A. (2014). Vascular Endothelial Growth Factor and Angiogenesis in the Regulation of Cutaneous Wound Repair. Advances in wound care, 3(10), 647-661. https://doi.org/10.1089/wound.2013.0517

Karu T. I. (2008). Mitochondrial signaling in mammalian cells activated by red and near-IR radiation. Photochemistry and photobiology, 84(5), 1091-1099. https://doi.org/10.1111/j.1751-1097.2008.00394.x

Kido, H. W., Oliveira, P., Parizotto, N. A., Crovace, M. C., Zanotto, E. D., Peitl-Filho, O., Fernandes, K. P., Mesquita-Ferrari, R. A., Ribeiro, D. A., \& Renno, A. C. (2013). Histopathological, cytotoxicity and genotoxicity evaluation of Biosilicate® glass-ceramic scaffolds. Journal of biomedical materials research. Part A, 101(3), 667-673. https://doi.org/10.1002/jbm.a.34360

Kido, H. W., Brassolatti, P., Tim, C. R., Gabbai-Armelin, P. R., Magri, A. M., Fernandes, K. R., Bossini, P. S., Parizotto, N. A., Crovace, M. C., Malavazi, I., da Cunha, A. F., Plepis, A. M., Anibal, F. F., \& Rennó, A. C. (2017). Porous poly (D,L-lactide-co-glycolide) acid/biosilicate® composite scaffolds for bone tissue engineering. Journal of biomedical materials research. Part B, Applied biomaterials, 105(1), 63-71. https://doi.org/10.1002/jbm.b.33536

Kubota, T., Hasuike, A., Ozawa, Y., Yamamoto, T., Tsunori, K., Yamada, Y., \& Sato, S. (2017). Regenerative capacity of augmented bone in rat calvarial guided bone augmentation model. Journal of periodontal \& implant science, 47(2), 77-85. https://doi.org/10.5051/jpis.2017.47.2.77

Lin, Z., Solomon, K. L., Zhang, X., Pavlos, N. J., Abel, T., Willers, C., Dai, K., Xu, J., Zheng, Q., \& Zheng, M. (2011). In vitro evaluation of natural marine sponge collagen as a scaffold for bone tissue engineering. International journal of biological sciences, 7(7), 968-977. https://doi.org/10.7150/ijbs.7.968 
Lopez-Heredia, M. A., Sa, Y., Salmon, P., de Wijn, J. R., Wolke, J. G., \& Jansen, J. A. (2012). Bulk properties and bioactivity assessment of porous polymethylmethacrylate cement loaded with calcium phosphates under simulated physiological conditions. Acta biomaterialia, 8(8), 3120-3127. https://doi.org/10.1016/j.actbio.2012.05.007

Luvizuto, E. R., Queiroz, T. P., Margonar, R., Panzarini, S. R., Hochuli-Vieira, E., Okamoto, T., \& Okamoto, R. (2012). Osteoconductive properties of $\beta$ tricalcium phosphate matrix, polylactic and polyglycolic acid gel, and calcium phosphate cement in bone defects. The Journal of craniofacial surgery, 23(5), e430-e433. https://doi.org/10.1097/SCS.0b013e31825e4abf

Magri, A. M., Fernandes, K. R., Assis, L., Mendes, N. A., da Silva Santos, A. L., de Oliveira Dantas, E., \& Rennó, A. C. (2015). Photobiomodulation and bone healing in diabetic rats: evaluation of bone response using a tibial defect experimental model. Lasers in medical science, 30(7), $1949-1957$. https://doi.org/10.1007/s10103-015-1789-3

Matsumoto, M. A., Caviquioli, G., Biguetti, C. C., Holgado, L., Saraiva, P. P., Rennó, A. C., \& Kawakami, R. Y. (2012). A novel bioactive vitroceramic presents similar biological responses as autogenous bone grafts. Journal of materials science. Materials in medicine, 23(6), 1447-1456. https://doi.org/10.1007/s10856$012-4612-8$

Mokoena, D., Dhilip Kumar, S. S., Houreld, N. N., \& Abrahamse, H. (2018). Role of photobiomodulation on the activation of the Smad pathway via TGF- $\beta$ in wound healing. Journal of photochemistry and photobiology. B, Biology, 189, 138-144. https://doi.org/10.1016/j.jphotobiol.2018.10.011

Moura, J., Teixeira, L. N., Ravagnani, C., Peitl, O., Zanotto, E. D., Beloti, M. M., Panzeri, H., Rosa, A. L., \& de Oliveira, P. T. (2007). In vitro osteogenesis on a highly bioactive glass-ceramic (Biosilicate). Journal of biomedical materials research. Part A, 82(3), 545-557. https://doi.org/10.1002/jbm.a.31165

Noba, C., Mello-Moura, A., Gimenez, T., Tedesco, T. K., \& Moura-Netto, C. (2018). Laser for bone healing after oral surgery: systematic review. Lasers in medical science, 33(3), 667-674. https://doi.org/10.1007/s10103-017-2400-x

Oliveira, F. S., Pinfildi, C. E., Parizoto, N. A., Liebano, R. E., Bossini, P. S., Garcia, E. B., \& Ferreira, L. M. (2009). Effect of low level laser therapy (830 nm) with different therapy regimes on the process of tissue repair in partial lesion calcaneous tendon. Lasers in surgery and medicine, 41(4), 271-276. https://doi.org/10.1002/lsm.20760

Parisi, J. R., Fernandes, K. R., Avanzi, I. R., Dorileo, B. P., Santana, A. F., Andrade, A. L., Gabbai-Armelin, P. R., Fortulan, C. A., Trichês, E. S., Granito, R. N., \& Renno, A. (2019). Incorporation of Collagen from Marine Sponges (Spongin) into Hydroxyapatite Samples: Characterization and In Vitro Biological Evaluation. Marine biotechnology (New York, N.Y.), 21(1), 30-37. https://doi.org/10.1007/s10126-018-9855-z

Parisi, J. R., Fernandes, K. R., Aparecida do Vale, G. C., de França Santana, A., de Almeida Cruz, M., Fortulan, C. A., Zanotto, E. D., Peitl, O., Granito, R. N., \& Rennó, A. (2020). Marine spongin incorporation into Biosilicate ${ }^{\circledR}$ for tissue engineering applications: An in vivo study. Journal of biomaterials applications, 35(2), 205-214. https://doi.org/10.1177/0885328220922161

Pinto, K. N., Tim, C. R., Crovace, M. C., Matsumoto, M. A., Parizotto, N. A., Zanotto, E. D., Peitl, O., \& Rennó, A. C. (2013). Effects of biosilicate(®) scaffolds and low-level laser therapy on the process of bone healing. Photomedicine and laser surgery, 31(6), 252-260. https://doi.org/10.1089/pho.2012.3435

Pisani, P., Renna, M. D., Conversano, F., Casciaro, E., Di Paola, M., Quarta, E., Muratore, M., \& Casciaro, S. (2016). Major osteoporotic fragility fractures: Risk factor updates and societal impact. World journal of orthopedics, 7(3), 171-181. https://doi.org/10.5312/wjo.v7.i3.171

Santinoni, C. D., Oliveira, H. F., Batista, V. E., Lemos, C. A., \& Verri, F. R. (2017). Influence of low-level laser therapy on the healing of human bone maxillofacial defects: A systematic review. Journal of photochemistry and photobiology. B, Biology, 169, 83-89. https://doi.org/10.1016/j.jphotobiol.2017.03.004

Sarvestani, F. K., Dehno, N. S., Nazhvani, S. D., Bagheri, M. H., Abbasi, S., Khademolhosseini, Y., \& Gorji, E. (2017). Effect of low-level laser therapy on fracture healing in rabbits. Laser therapy, 26(3), 189-193. https://doi.org/10.5978/islsm.17-OR-14

Shakouri, K., Eftekharsadat, B., Oskuie, M. R., Soleimanpour, J., Tarzamni, M. K., Salekzamani, Y., Hoshyar, Y., \& Nezami, N. (2010). Effect of low-intensity pulsed ultrasound on fracture callus mineral density and flexural strength in rabbit tibial fresh fracture. Journal of orthopaedic science : official journal of the Japanese Orthopaedic Association, 15(2), 240-244. https://doi.org/10.1007/s00776-009-1436-6

Silva, T. H., Moreira-Silva, J., Marques, A. L., Domingues, A., Bayon, Y., \& Reis, R. L. (2014). Marine origin collagens and its potential applications. Marine drugs, 12(12), 5881-5901. https://doi.org/10.3390/md12125881

Skondra, F. G., Koletsi, D., Eliades, T., \& Farmakis, E. (2018). The Effect of Low-Level Laser Therapy on Bone Healing After Rapid Maxillary Expansion: A Systematic Review. Photomedicine and laser surgery, 36(2), 61-71. https://doi.org/10.1089/pho.2017.4278

Sousa, T. H. S., Fortulan, C. A., Antunes, E. S., \& de M. Purquerio, B. (2008). Concept of a Bioactive Implant with Functional Gradient Structure. Key Engineering Materials, 396-398, 221-224. https://doi.org/10.4028/www.scientific.net/kem.396-398.221

Swatschek, D., Schatton, W., Kellermann, J., Müller, W. E., \& Kreuter, J. (2002). Marine sponge collagen: isolation, characterization and effects on the skin parameters surface-pH, moisture and sebum. European journal of pharmaceutics and biopharmaceutics : official journal of Arbeitsgemeinschaft fur Pharmazeutische Verfahrenstechnik e.V, 53(1), 107-113. https://doi.org/10.1016/s0939-6411(01)00192-8

Tim, C. R., Bossini, P. S., Kido, H. W., Malavazi, I., von Zeska Kress, M. R., Carazzolle, M. F., Parizotto, N. A., \& Rennó, A. C. (2015). Effects of low-level laser therapy on the expression of osteogenic genes during the initial stages of bone healing in rats: a microarray analysis. Lasers in medical science, 30(9), 2325-2333. https://doi.org/10.1007/s10103-015-1807-5

Ueno, F. R., Kido, H. W., Granito, R. N., Gabbai-Armelin, P. R., Magri, A. M., Fernandes, K. R., da Silva, A. C., Braga, F. J., \& Renno, A. C. (2016). Calcium phosphate fibers coated with collagen: In vivo evaluation of the effects on bone repair. Bio-medical materials and engineering, 27(2-3), 259-273. https://doi.org/10.3233/BME-161581

Wu, M., Chen, G., \& Li, Y. P. (2016). TGF- $\beta$ and BMP signaling in osteoblast, skeletal development, and bone formation, homeostasis and disease. Bone research, 4, 16009. https://doi.org/10.1038/boneres.2016.9 